May 2. "Mr. Harvey of St. Bartholomew's Hospital brought Ten Gentlemen Students at that Hospital to the Museum." These were probably the first visitors to the Museum apart from Members of the Court of Assistants or of the College staff. in 3 " May 3. " 1800 ]. Hawkins [Master in the inaugural year of the College, 1800] and his friend called to see the Museum," and there arrived " A Mummy in a Glass case from Thebes," which Anthony Carlisle subsequently unrolled before a select audience.

On May 17 there came the first American visitor, "a friend of Sir W. Blizard's, to see the Museum.'

On the 25th came the widow of John Hunter with Mrs. Campbell (Agnes Hunter).

July 12. "Received the Ostrich from Exeter Change, for which Mr. Fome paid Mr. Polito's man £5 5s.'

Later, arrived a lama at the price of two guineas.

The Museum, now fully installed, was first opened to visitors for two days weekly on May 18th, 1813. On June 11th, 1816, " the Museum opened to visitors for June, July, and August." Clift seems to have made a point of showing visitor's round the collection, then, as now, unrivalled. In his zealous, unaffected way, he gave his explanations to all and suudry, to students as well as to distinguished laymen. Among the former we may imagine John Keats to have been included, for we know from the College books that in the year 1816 a ticket was issued to him for Sir William Lawrence's lectures, which lasted, as Clift notes, from March 21st to May 13th, when the fifteenth and last lecture was delivered. The second lecture was, "On the Various Theories concerning Life, at various periods of the world." 'I'his may have excited comment, for in 1826 Lawrence, we know, got into difficulties in a publication held by his opponents to be disiespectful to "the dignity of mau." Another notable course of lectures that year was from Abernethy, who was opposed to Lawrence's materialistic views. Our discreet diarist, however, never offers comment or criticism on the ideas or utterances of the Court of Assistants, and we only very rarely obtain a glimpse of his private opinions, as when he notes that $\mathrm{Mr}$. George Shaw, thin roologist, to whom the College presented a gold tea and coffee service, was "a dunce." Shaw's crime may have been that of getting others to do his business for lim in the many rolumes of his finely illustrated treatise on Natural History, the plates of which are manifestly not his own work. Clift hated plagiarism, and that the services of literary ghosts should go unacknowledged. Hunter was, in a sense, ghost to Sir Everard Ifome, and Clift more than suspected the latter of using Hunter's notes and then destroying them. Home thus built up a high reputation which was not properly his, and Clift never forgave him. When Home, driving with him in a post-chaise, confessed to his destruction of the Hunter papers in 1823, he was so taken aback that he could only stutter: "Well, Sir Everard, there is but one thing more to be doue, that is to destroy the collection." 'The death of Home (September 1st, 1832) is recorded by Clift in the Diary by the insertion of a biographical notice, quoted from a journal, at the end of which ho writes grimly, in brackets, "Sic transit gloria mundi."

He did not attend Sir Everard's funeral or that of Sir Astley Cooper, but on Sunday, January 7th, 1821, we read, "Mrs. Hunter died this morning. Aged 79." Clift calculates that she was twenty-four years younger than John Hunter at the time of their marriage. She was buried at noon on January 15th, the mourners being Dr. Baillie and Sir Everard Home (brother), William Hunter Baillie and Villiam Clift, and two other gentlemen, of whom one was a painter. These were conveyed in two mourning coaches from Mrs. Hunter's house in Holles Street, Cavendish Square, " a white house," says the diarist, " east side above the middle." The coflin was buried in a vault under the new church, Ma:ylebone. "Lady Campbell (Agnes Hunter)," continues Clift, " remained in Holles Street, and, of course, did not appear." "Mrs. Hunter had been de. clining in health and strength gradually for some time. Dr. Baillie and Sir Everard Home thought it useless to drench her with Medicine; as she had little appetite they supported her with Cordials, such as weak brandy and water, \&c. Being very fair, and her hair like Flax, her Teeth had failed her for several years; and consequently her digestion did not improve."

Of Clift's activities outside the College, such as the dissection of the bodics of criminals who had been hanged, his joulneys in search of specimens, or the relations of the College with arctic and other explorers, some account may be given at a future date.

\section{THE OPERATIVE TREATMENT OF MALIGNANT DISEASE.}

Bradshaw Lecture by Mr. H. J. Waring.

AT the Royal College of Surgeons of England, on December 14th, the Bradshaw Lecture was delivered by Mr. H. J. Waring, Fellow of the College, on "The operative treatment of malignant disease, its possibilities and limitations."

Mr. WARING said that he proposed to confine himself to the conclusions at which he had arrived as a result of his own work and observation during the last twenty-five years, and to bring forward no references to literature or to statistics. Statistics in this instance were misleading, because many patients, especially hospital cases, were reported as cured and passed out of the observation of the operating surgeon, but afterwards developed recurrence and sought treatment elsewhere.

Commencement and Site of Malignant Disease.

Pathologists had not yet succeeded in demonstrating the actual mode of commencement of a malignant tumour. Probably the process was essentially a local one, and only after the growth had become well established did it invade adjacent tissues or cause the formation of secondary growths. The growth having infiltrated into the various connective tissue layers, a few cells might be detached, and, carried by the blood or lymph streams, give rise to secondary growths in other parts of the body. 'The parts in the immediate neighbourhood of a new growth usually, in varying degrees, formed a natural barrier to its extension and therefore, from the surgical point of view, in all malignant disease the affection should be regarded as really a local one, and upon the extent to which this was the case depended the possibilities of successful operation.

The first important consideration was the site of the disease. When malignant disease attacked a tissue or organ near the surface of the body the patients usually sought skilled advice at an early stage, and this permitted of surgical interference in a way that promised success. In cases in which the tongue was affected, for instance, people, at all events among the educated classes, came for advice early, although this did not hold good in the case of people of the artisan class, especially if they had no effective dental service available, and the results in consequence were less satisfactory. But in the case of affected tonsils, on the other hand, the disease often was not manifest to the patient until a much later period in its development; indeed, epithelioma of the tonsils might not bo noticed until the adjacent vessels were well involved.

The determining importance of the site of the disease was illustrated in such cases as carcinoma of the oesophagus, which was very difficult to approach surgically, and, even if the anatomical difficulties were overcome, the patients almost invariably died from secondary haemor. rhage. The stomach was frequently, in the later decades of life, the site of a carcinoma, and up to the present the surgical results had not been as satisfactory as one would wish. This was due to a great extent to the difficulty of early diagnosis. The tumour could not be readily felt, and the disease was often not treated until the lymph glands and other structures had become infected. 'T'he pancreas was another deep-seated organ, and the symptoms which followed from malignant disease of the pancreas were not very definite, so that by the time the disease was noted it was often too extensive to eradicate. He had operated for carcinoma of the pancreas in three cases, but two of the patients died after operation, and the third only recovered to die later from secondary growtlus.

\section{Primary and Secondary Growths and Types of} Carcinoma.

The extent and connexions of the primary disease had next to be considered. Some growths, while extending quite markedly, would remam with margins well differentiated from the surrounding tissues, and here the prospect of operative treatment was good ; wut othershe slowed in illustration a growth in the pelvis of the kidney extending to the ureter-had no clear line of demaycation, and in such cases there was likely to be a swift recurrence after operation. Secondary growths were most commonly developed in the lymph glands. An 
infiltrating growth of the tongue, ever. $f$ it were recognized at an early stage, might set up a secondary growth which rendered further operative procedures of doubtful benefit. When the growth involved the lymph glands largely and the connective tissues showed signs of oedema, the case might be said to be beyond surgery. On the other hand, columuar-cell carcinoma of the large intestine and rectum might exist for a long time before it set up secondary growths, and such a condition was very amenable to surgery, provided it was diagnosed early. Considerable stress was sometimes laid on diagnosis by $x$.ray examination of the intestinal tract. The lecturer thought that $x$-ray worker:s were rather inclined to make diaguoses which were not justified by clinical experience. He would not advise reliance on the $x$-ray findings to determine whether or not an operation. should take place in columnar-cell carcinoma. The primary grow ths appeared to have, in some cases, a marked influence on the further increase in size of the secondary growths. The cause of this was not clear to him; he only knew that it was so as a result of clinical observation.

From the clinical point of view carcinoma might be said to consist of four varieties: (1) The exuberant, or "cauliflower," type; (2) the ulcerative type, which was fairly satisfactory in operation; (3) the infiltrating type, which surgically was the least satisfactory of all; and (4) the scirrhus type, with a large amount of fibroid tissue, met with particularly in the breast, and giving fairly satisfactory results in treatment. Oecasionally a tumour which had existed for a long time and had been regarded as non-malignant would become malignant; it was always well for the surgeon to bear in mind that possibility. The more the cells of a malignant growth approximated to the type and size and characteristics of the cells of the tissue from which it had been taken, the greater was the likeli. hood of the success of the operative procedure. The more remote histologically, the smallor the prospects of success. Usually the vital characteristics of the cells of a maliguant tumour could not be estimated until the growth had been removed and a histological examination made. But the vascularity of the growth and its mode of extension was of assistance in prognosis. A very vascular tumour with cells extending widely from the margins indicated the less favourable condition.

The reaction of the tissues immediately adjacent to the malignant growth was an important factor. Genorally the tissues were resistant, and sometimes formed a fibrous barrier, so that the growth was localized, its extension limited, and its invasion of the lymph and blood vessels delayed, but, on the other hand, the tissues appeared sometimes to offer no barrier, and then the case was exceedingly grave.

Characteristics of Patient and Decision as to Operation. The vital characteristics of the patient and the coexistence of other diseases had also to be reckoned with. Patients who were naturally obese were not usually good subjects for operation, owing to the ease with which a malignant tumour invaded fatty tissues, and also in certain cases to their diminished power of repair. The patient's age was of some importance. Carcinoma in the elderly was of slower growth than in the young. In carcinoma of the breast in a woman of 30 , or of the tongue in a man of 30 , the operation was likely to be less successful, other things being equal, than in a similar case with a man or woman 20 years older. Some surgeons were averse from removing malignant growths in people of advanced age, but age was not a barrier to the per. formance of an operation unless the patients had other affections which militated against success.

Preliminary excision of a portion of the supposed malignant growth before operation, in order to confirm the clinical diagnosis and decide the kind and extent of operation to be performed, was a practice which could not be too strongly condemned, as the necessary cutting might cause the starting of new growths. Careful clinical examination by a slsilled diagnostician would, in practically all cases, avoid the necessity for such a procedure. Where some such course was demanded; the growth should be removed as far as seemed practicable, and, alter investigation, the oneration completed in the appropriate way. All the clinical facts should be communicated to the pathologist. Clinical examinations of supposed malignant tumours should be carefully carried out, and when the diagnosis was once made further repeated examinations should be deprecated because they were likely to lead to the detachment of cells from the tumour and establish secondary growths. Evcry operation for radical cure should have for its objective the complete removal of the primary focus of the diseass. Unfortu. rately, operations were sometimes done by surgeons whose anatomical knowledge was not as complete as it should be. The results of surgical procedure would be more favourable with the earlier diagnosis of the disease and immediate operative treatment by a skilled surgeon versed in the anatomy of the part.

\section{$X$ Rays and Radium.}

The lecturer referied, in conclusion, to the value of $x$ rays and radium in complementing or replacing surgical procedures. $X$ ray applications previous to the performance of an operation had been adrocated by many. In his own experience he had not been able to assuie himself that there were any advantages from this pre. operative treatment. One of its effects was to cause the tissues in the region of the growth to become indurated. In the case of carcinoma of the breast and other superficial tumours it might be an advantage to apply $x$ rays after operation in order to destroy any scattered or detached cells outside the operative field. It was essential to the successful treatment of malignant disease that all malignant cells should either be removed by operation or destroyed in silu, and agents such as $x$ rays and radium offered the only means of attaining the second result. There was no doubt that $x$ rays and radium exerted a marked effect on the growth of cells in many maliguant tumouts. A previous injection of a salt of copper was said to assist in the destruction of the tumoar cells by $x$ rays, and physicists with whom he had discussed the matter thought that the introduction of copper was likely to cause the cells to be more subject to $x$ ray action.

The empirical application of $x$ rays and radium in the treatment of all cases of malignant disease was strongly to be deprecated. - Recently an improved $x$-ray apparatus had been introduced, and with this it was claimed that the rays could be effectively applied to deep-seated tissues. The powers of this therapy had been very much exaggerated in the lay press. His own belief was that the frequent result of $x$-ray treatment of operable growths was to render them inoperabie. One of the chief reasous for failure in cases tieated by $x$ rays was that the radio. logists who had treated the patients had had insulficicnt clinical experience. A few weeks previously he had been visiting Germany, and he went to one of the centres where deep $x$-ray therapy was practised. There he found all kinds of patients being treated by $x$ rays, and it appeared to lim that while the $x$-ray operators wero highly competent in their own technique they were less familiar than they should be with clinical medicine. He asked one of the authorities to show him a cured case, and a patient who had been treated for carcinoma of the breast was brought for his inspection. Undoubtedly the breast carcinoma had shrivelled up a great deal, but the growth had spread into the axillary region, where he found a considerable secondary growth adherent to the lymphatic structures. He indicated this to the $x$-ray specialist, who lowever, said that there was nothing in it of importance! Mr. Waring insisted that in cases in which $x$ ray treat. ment was given the $x$-ray operator and the clinician should worls in close conjunction. In his opinion, up to the present time many more cases had been rendered inoperable, and therefore incurable, by $x$ rays and radium than had been cured by these agents. The place of $x$ rays and radium was in surgically inoperable cases, where much alleviation of suffering and some prolongation of days might be obtained from radiotherupy.

THE next annual meeting of Freuch-speaking neurologists will be held at Quimper in the first week of August, 1522 , under the presidency of Professor Jean Lépine, of Lyons, when the following subjects will be discussed: (1) Mental disturbances in epidemic encephalitis, introduced by Drs. 'Truelle and Petit; (2) Lesions of the central uervous system in motor restlessness and muscular rigidity, introduced by Di. Anglade, of Bordeaux; (3) Care of the insane and protection of the rights of the individual and society, introduced bv lor. Courbon. of stéphansfeld. 